This Section of Epidemiology and Psychiatric Sciences appears in each issue of the Journal and is dedicated to all forms of creative production born of an intimate and individual urge, often secretive, unbound from the conventional art system rules. Through short descriptions of the Outsider art work of prominent artists and new protagonists often hosted in community mental health services, this section intends to investigate the latest developments of the contemporary art scene, where the distances between the edge and the center are becoming more and more vague.

Carole Tansella, Section Editor

\title{
Marcel Schmitz: tape planner
}

\section{E. Dejasse*}

Conservation, Research E Dissemination, La 'S' Grand Atelier, Vielsalm, Belgium

Received 5 June 2017; Accepted 26 June 2017; First published online 9 August 2017

Key words: Architecture, art brut, comics, outsider art.

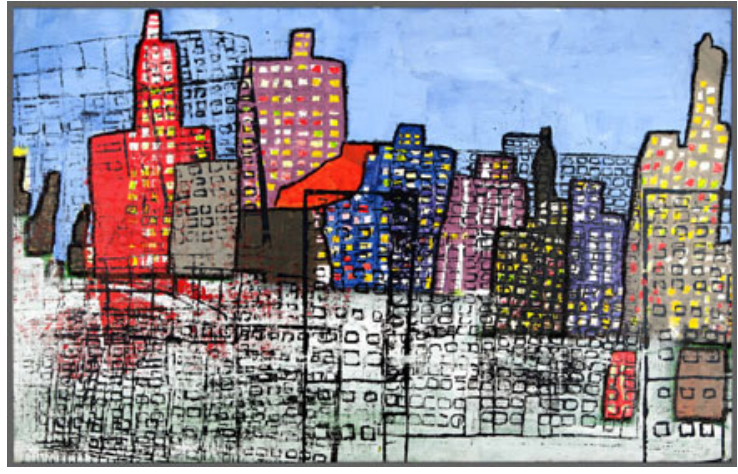

Fig. 1. Vivre à FranDisco. Exhibition at Brass - Centre culturel de Forest, Brussels, 2017 (c) Rozenn Quere.

Marcel Schmitz is born in 1966. From 2007 till today he has attended La ' $\mathrm{S}$ ' Grand Atelier, an artistic studio located in Vielsalm in the rural south of Belgium. Founded in 1992, it is a place where people with mental disabilities can develop their artistic potential. They are supervised by facilitators whose role is to help them through dialogue and technical support. La ' $S$ ' defines itself as laboratory of artistic mix. They also

* Address for correspondence: E. Dejasse, Conservation, Research \& Dissemination, La 'S' Grand Atelier, Vielsalm, Belgium

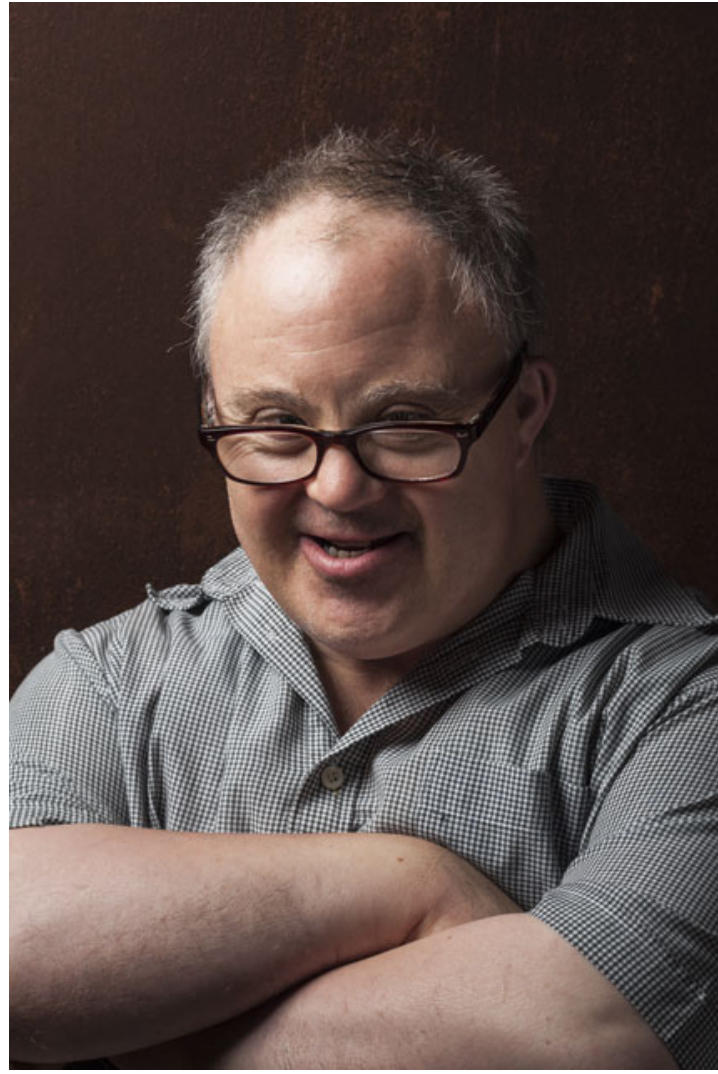

Fig. 2. Amandine Nandrin, Portrait of Marcel Schmitz, 2015. 
regularly invite contemporary artists to collaborate with their creators (Rouche, 2014).

At an early stage, Marcel Schmitz began to depict architecture using a wide range of techniques: black and white pencil drawings, acrylic on canvas, monotypes or linocuts that he sometimes mixes with collages. Although suffering from vertigo, his work shows a fascination with sprawling cities full of skyscrapers. Marcel Schmitz's megacities seem to have been built to accommodate millions of people. However, during many years, they were free of any inhabitants, as if they were playgrounds where he could virtually project himself.

In the very beginning, his buildings were shown in plan view or in full frontal view. Later, he timidly attempted to portray depth by using oblique projection; notably, when representing San Francisco Oakland Bay Bridge. Later yet, he started to overlay constructions one on the other; for example, by painting a first row of skyscrapers with acrylic over which he would print a second row with monotype technique. All these experiments reflect a willingness to step outside the frameworks and to develop his town planning aspirations to their fulfilment. After collecting advice from the studio facilitators, he constructed his first three-dimensional (3D) building. He quickly found his unique technique by using cardboard pieces that he joins together and covers with adhesive paper tape, giving his constructions their typical white-pale yellow colour. After having made three or four building, he decided that these were part of a town he christened FranDisco!

Marcel Schmitz reinvents the language in a very original and funny way. The most famous French singers as well as the people he stays with in his everyday life are renamed: 'Géraldine' becomes 'Gérardine' and 'Clémentine' becomes 'Clairementine'; he says he has 'frisomy' disorder and most of all, he describes himself as a 'rubaniste' - in French 'urbaniste' means 'town planner' when 'ruban adhésif' means 'adhesive tape'.

One of the very first FranDisco's building is the Church-Tunnel, which allows you to receive an express Sacrament without stepping out of your car and so be ready to directly go on to your holidays. We can also mention the Holy Water Fountain - having grown in the Belgian Ardenne, a traditionally catholic region, the religious elements are present everywhere. The panoramic balcony is the place where you can have a Fanta can with Laurence - one of Marcel Schmitz's educator. Even his paintings and drawings can been seen here. Marcel Schmitz pastes copies of his two dimensional works on the buildings or inside them, renewing the principle of the 'mise en abyme'. The facilitators, other artists from $\mathrm{La}$ ' $\mathrm{S}$ ', a curious house in a town he has just visited, his First Communion, the Saint-Nicolas Day, a commercial or an episode of MacGyver seen on $\mathrm{TV}$, all these past and present experiences feed into FranDisco. Through it, the artist's everyday life is reinterpreted in an always poetic and wacky way.

Cartoonist Thierry Van Hasselt - a regular collaborator of $\mathrm{La}$ ' $\mathrm{S}$ ' - has begun to gather these anecdotes and to sketch the town from every angle. These were the baseline of 'Living In FranDisco' a comic that takes place in the burgeoning megacity, depicting the 'tape planner' in his everyday and dreamlife (Van Hasselt \& Schmitz, 2016). Marcel Schmitz not only gave the script outline but finally also collaborate to the drawing of the pages. This book was enthusiastically received by the press and was even listed as eligible for an award at 2017 famous Angoulême Comics Festival.

For some time now, the cartoonist and 'tape planner' has been participating in residencies at several museums and cultural centres or during artistic events. At those same places, Thierry Van Hasselt draws his comics pages, while Marcel Schmitz simultaneously keeps on building FranDisco. They share life experiences that finally find their concrete expression in the cardboard city itself: some places where they spent time during these residencies - Geneva's NH Hotel, the Victor Vasarely Foundation in Aix-en-Provence, even Van Hasselt's house - all appear in FranDisco. Schmitz's cardboard and tapes construction, now covering more than $50 \mathrm{~m}^{2}$, is a 3D diary where reality and fantasy merge together. It is the expression of a fundamental trend in visual art since at least the mid-20th century based on the entanglement of life and art.

\section{References}

Rouche A-F (ed.) (2014). Knock Outsider!. Frémok: Brussels. Van Hasselt T, Schmitz M (2016). Vivre à FranDisco. Frémok: Brussels.

\section{About the author \\ Erwin Dejasse has a Ph.D. in art history and is an exhi- bitions curator, academic researcher and lecturer spe- cialised in comics. He writes also regularly about art brut and other visual art forms at the margin. He is currently in charge of the preservation, research and dissemination of La 'S' Grand Atelier's art collection.}

Carole Tansella, Section Editor 